\title{
Assessment of the aquatic environment quality of high Andean lagoons using multivariate statistical methods in two contrasting climatic periods
}

\author{
María Custodio ${ }^{1 *}$, Richard Peñaloza², Fernán Chanamé1, Raúl Yaranga', \\ Rafael Pantoja' \\ 1 Universidad Nacional del Centro del Perú, Facultad de Zootecnia, Instituto de Investigación en Alta Montaña, \\ Av. Mariscal Castilla No. 3989-4089, Huancayo, Perú \\ 2 Universidad Nacional Agraria La Molina, Av. La Molina s/n La Molina, Lima, Casilla Lima 12, Perú \\ *Corresponding author's e-mail: mcustodio@uncp.edu.pe
}

\begin{abstract}
The quality of the aquatic environment of high Andean lagoons was evaluated by means of multivariate statistical methods in two contrasting climatic periods. The water samples and benthic macroinvertebrates were collected in 22 sampling sites during the rainy and dry seasons. In each lagoon DO, DTS, EC, temperature and pH were determined in situ. The results revealed that the physicochemical parameters comply with the environmental quality standards for water, except $\mathrm{COD}$ and $\mathrm{BOD}_{5}$. In the PCA of the physicochemical parameters, the first two axes explained $73 \%$ of the total variation. The gradual analysis in pairs showed significant differences. The SIMPER analysis determined an average of four families of benthic macroinvertebrates per lagoon that showed more than $70 \%$ contribution. The ANOSIM revealed that Tragadero lagoon differs significantly from the others. The DistLM showed a value of 0.46 of coefficient of determination. Therefore, the quality of the environment of high Andean lagoons evaluated by means of multivariate statistical methods presents important differences or dissimilarities not only in the physicochemical characteristics of the water, but also in the composition of the benthic macroinvertebrate communities.
\end{abstract}

Keywords: aquatic environment, high Andean lagoons, benthic macroinvertebrates, water quality.

\section{INTRODUCTION}

Water is the renewable natural resource that exercises the most limiting action in human development and in all forms of life [Bharti 2011]. The availability and quality of water is a concern for humanity, due to the increasing deterioration that continental aquatic ecosystems are experiencing as a result of natural and anthropogenic pressures. Therefore, the control of water quality has become very important to maintain the sustainability of water resources [Wen et al. 2012]. In developed countries, Strategic Framework Directives have been implemented, such as the Water Framework Directive, basin and marine water quality in 2000 (WFD, 2000/60/EC), 2006 (QBWD, 2006/7/EC) and 2008 (MSFD, 2008/56 / EC), respectively
[Petus et al. 2014]. On the other hand, in developing countries, the supply and treatment of water are the most important issues and they allocate most of the investments in water management. However, in practice, less than $20 \%$ of the total wastewater effluents are treated before they are discharged into water bodies [Swiech et al. 2012, Seiler et al. 2015].

In Peru, water pollution is one of the biggest environmental problems, not only due to the rapid growth of the country's urban centers, but also due to the large volumes of wastewater that it generates. Currently, it is estimated that wastewater is treated only in $29.1 \%$ through 143 treatment plants, the rest being discharged without any treatment to the continental surface water bodies and the sea [MINAM 2011]. Degrada- 
tion of water quality directly affects all types of water applications [Article 2015]; for example, the population and recreational use, coastal and continental marine extraction and cultivation activities, the irrigation of vegetables and animal drink, as well as the use for the conservation of the aquatic environment.

The focus of water quality monitoring in Peru is based on the comparison of physical, chemical and bacteriological parameters with environmental quality standards for water established by the Ministry of the Environment. However, the use of this methodology allows identifying sources of pressure, but does not enable to better understand the processes of alteration of water quality. The complex data matrices that are generated in each monitoring need to be systematized and analyzed with various statistical methods. The application of multivariate statistical methods for data analysis offers a better understanding of the quality of the aquatic environment [Muangthong and Shrestha 2015].

In this context and given the reduced importance that continental aquatic ecosystems receive, which become increasingly fragile in the face of natural and anthropogenic pressures, the need to apply tools that allow monitoring the quality of these ecosystems arises in order to achieve a sustainable management of these resources. The objective of the study was to evaluate the quality of the aquatic environment of high Andean lagoons by means of multivariate statistical methods in two contrasting climatic periods.

\section{MATERIAL AND METHODS}

\section{Description of the study area}

The Pomacocha, Tragadero, Cuncancocha, Incacocha and Ñahuinpuquio lagoons considered in the study are located in the Mantaro river basin. Which is located in the Central Andes of Peru, between latitudes: $10^{\circ} 34^{\prime} \mathrm{S}-13^{\circ} 35^{\prime} \mathrm{S}$ and longitudes: $73^{\circ} 55^{\prime} \mathrm{W}-76^{\circ} 40^{\prime} \mathrm{W}$, with altitudes ranging from 500 masl to 5350 masl (Figure 1). Associated with these lagoons are bofedales with typical vegetation cover (Distichia muscoides and Oxychloe andina).

\section{Sampling and measurement procedures}

The water samples and benthic macroinvertebrates were collected in five lagoons, in 22 sampling sites. In each lagoon, dissolved oxygen $(\mathrm{mg} / \mathrm{L})$, total dissolved solids $(\mathrm{mg} / \mathrm{L})$, conductivity $(\mu \mathrm{S} / \mathrm{cm})$, temperature $\left({ }^{\circ} \mathrm{C}\right)$ and $\mathrm{pH}$, were determined in situ by means of Hanna Instruments portable equipment. Additionally, the water samples were collected in sterile glass bottles for bacteriological analysis and in disposable plastic bottles of two liters for the analysis of nitrates,

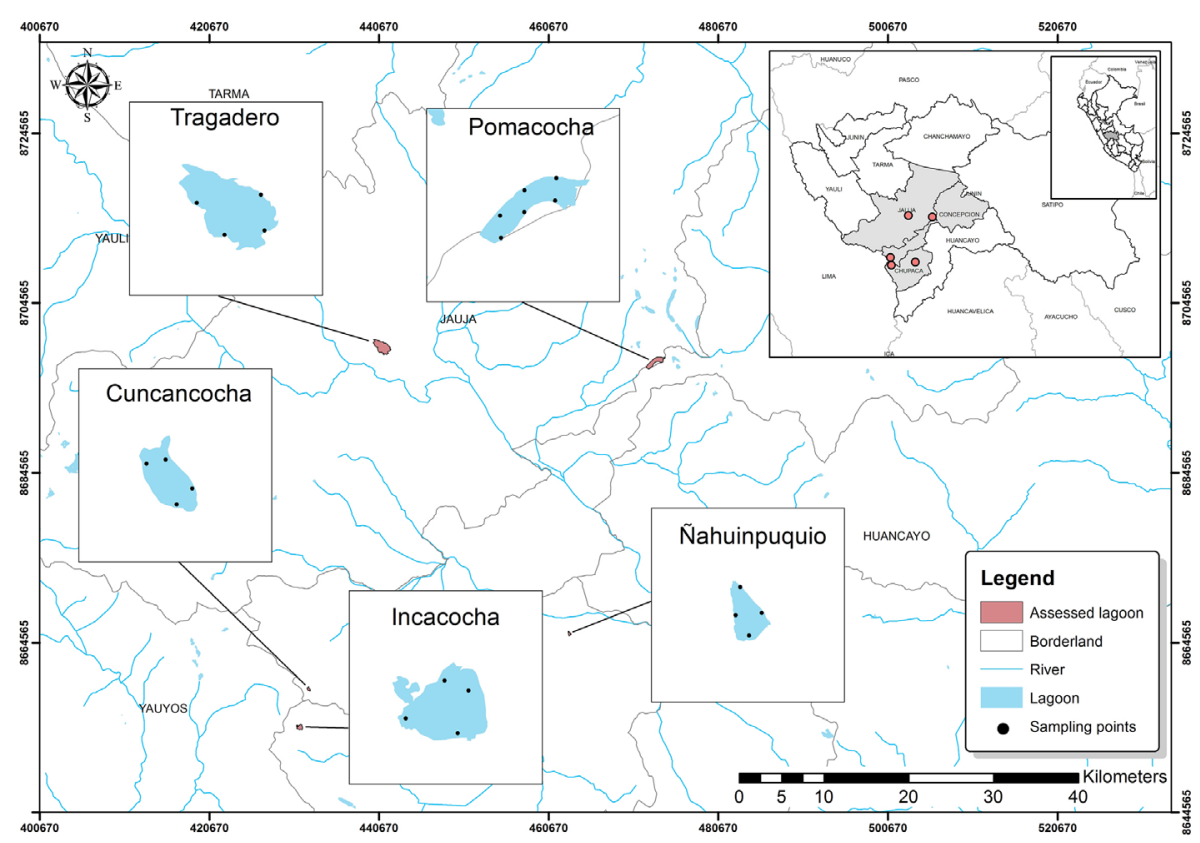

Figure 1. Geographical location of the study area and water sampling points and benthic macroinvertebrates in high Andean lagoons 
total phosphorus, $\mathrm{COD}, \mathrm{BOD}_{5}$ and heavy metals. Previously, the bottles were labeled, treated with a 10\% nitric acid solution for 24 hours and rinsed with bidistilled water. Then, one liter of water from each of the samples was added $1.5 \mathrm{~mL}$ of concentrated nitric acid, for conservation.

The preparation of the sample consisted of placing $250 \mathrm{ml}$ of water in a beaker, which was boiled, until obtaining $100 \mathrm{ml}$. Immediately, $5 \mathrm{ml}$ of nitric acid and $5 \mathrm{ml}$ of concentrated hydrochloric acid were added for the destruction of the organic matter and again it was boiled (until the water was consumed and a pasty consistency was obtained). It was allowed to cool and then $10 \mathrm{ml}$ of distilled water was added, filtered and stuck in a $100 \mathrm{ml}$ fiola, with $1 \%$ nitric acid [Clesceri et al. 2012]. The quantitative determination of heavy metals (copper, zinc, iron and lead) was carried out with the flame atomic absorption spectrophotometry method, according to the methodology recommended by the FAO (1983), using an AA-6800 Atomic Absorption Spectrophotometer equipment, Shimadzu brand, for which the standard copper, zinc, iron and lead solutions were previously prepared and read in the increasing order of concentration, with which the calibration curve was prepared and then the samples were read. The collection of benthic macroinvertebrates was carried out using the Ekman-Birge dredger from Hydro-Bios. The samples were fixed with $70 \%$ alcohol to carry out the taxonomic determination later.

\section{Statistical data analysis}

The data on the lagoon factors and sampling season (rain and low water) were analyzed using the Primer-E v7 statistical package (Massey University, New Zealand) and PAST v3.19. Initially, the normality of the data was evaluated and then a Principal Component Analysis (PCA) was performed to analyze the physicochemical parameters of the water in the 22 sampling points. Next, we proceeded to evaluate the effects of the lagoon factors and sampling period with the PERMANOVA model of two factors with Euclidean distance for physicochemical parameters as a measure of similarity [Clarke and Gorley 2015].

The analysis of the general patterns of composition of benthic macroinvertebrate communities was carried out using the PCO method (analysis of principal coordinates, similarity of Bray-Curtis for Cluster analysis) in order to obtain the percep- tual map. Next, the PERMANOVA analysis was carried out to determine significant differences between the sites and distribution patterns of species and abundances [Clarke and Gorley 2006]. In order to determine the most influential taxa in the composition of the communities of benthic macroinvertebrates in each of the lagoons, an analysis of the similarity percentages (SIMPER) was conducted from a similarity matrix. Likewise, the ANOSIM similarity analysis was performed for the pair-wise biological comparison of the biological variables between lagoons and to find significant differences of the relative abundances of the macroinvertebrates between lagoons and seasons. The individual and group results of the macroinvertebrate communities were compared using MDS $2^{\text {nd }}$ stage [Ceschia et al. 2007], applying the Spearman range to determine the coefficient of similarity of the distribution in relation to the matrix of the physicochemical parameters.

The BioEnv method was used to identify the physicochemical parameters that have a strong correlation with macroinvertebrate communities and find the best explanation of spatial patterns [Ignatiades et al. 2009]. DistLM (linear model based on distance) was applied to obtain the value of permutational regression $\mathrm{R}^{2}$, of greater importance, between the matrices of biological variables and physicochemical parameters of water individually and in groups, in order to determine the contribution relative of these variables on the structure of benthic macroinvertebrate communities [Primo et al. 2012]. The analysis of BEST with $\mathrm{R}^{2}$ as a selection criterion was used to determine which of the physicochemical parameters of the water better explain the composition pattern of the macroinvertebrate community.

\section{RESULTS AND DISCUSSION}

\section{Analysis of water quality}

Table 1 shows the mean values and standard deviation of the physicochemical parameters of water quality of high Andean lagoons, considering the sampling period. The $\mathrm{pH}$ values of the water presented the variations in each of the lagoons evaluated, with the values ranging from $6,790 \pm 0.582$ in the Cuncancocha lagoon during the dry season to $8.611 \pm 0.190$ in the Incacocha lagoon, during the rainy season. These variations would be related to the edaphic conditions of the 
Table 1. Mean and standard deviation of water quality parameters at different sampling points of high Andean lagoons measured during the rain and dry periods

\begin{tabular}{|c|c|c|c|c|c|c|c|c|c|c|}
\hline \multirow{2}{*}{ Indicator } & \multicolumn{2}{|c|}{ Pomacocha } & \multicolumn{2}{|c|}{ Tragadero } & \multicolumn{2}{|c|}{ Cuncancocha } & \multicolumn{2}{|c|}{ Incacocha } & \multicolumn{2}{|c|}{ Ñahuinpuquio } \\
\hline & Rain & Dry & Rain & Dry & Rain & Dry & Rain & Dry & Rain & Dry \\
\hline $\mathrm{pH}$ & $6.841 \pm 0.126$ & $6.796 \pm 0.083$ & $7.563 \pm 0.415$ & $7.531 \pm 0.616$ & $7.159 \pm 0.248$ & $6.790 \pm 0.582$ & $8.611 \pm 0.190$ & $8.860 \pm 0.044$ & $7.634 \pm 0.058$ & $7.745 \pm 0.080$ \\
\hline $\mathrm{EC}(\mu \mathrm{S} / \mathrm{cm})$ & $254.244 \pm 3.033$ & $248.171 \pm 5.847$ & $269.813 \pm 7.503$ & $264.343 \pm 14.426$ & $260.352 \pm 4.390$ & $253.192 \pm 1.677$ & $262.534 \pm 4.024$ & $250.750 \pm 4.226$ & $258.771 \pm 41.41$ & $252.837 \pm 48.342$ \\
\hline $\mathrm{COD}(\mathrm{mg} / \mathrm{L})$ & $31.092 \pm 0.923$ & $30.581 \pm 1.025$ & $59.637 \pm 0.234$ & $56.492 \pm 0.690$ & $46.875 \pm 1.250$ & $45.388 \pm 0.216$ & $38.833 \pm 0.312$ & $37.167 \pm 0.136$ & $34.521 \pm 0.401$ & $33.813 \pm 1.055$ \\
\hline $\mathrm{BOD}_{5}(\mathrm{mg} / \mathrm{L})$ & $18.068 \pm 0.398$ & $18.079 \pm 0.466$ & $28.806 \pm 0.678$ & $28.430 \pm 0.754$ & $18.679 \pm 0.869$ & $18.442 \pm 2.081$ & $18.513 \pm 0.374$ & $18.413 \pm 0.285$ & $20.800 \pm 0.400$ & $20.704 \pm 0.537$ \\
\hline $\mathrm{DO}$ (mg/L) & $6.680 \pm 0.105$ & $6.628 \pm 0.159$ & $6.122 \pm 0.068$ & $6.016 \pm 0.209$ & $6.496 \pm 0.164$ & $6.384 \pm 0.114$ & $6.432 \pm 0.046$ & $6.376 \pm 0.017$ & $7.118 \pm 0.083$ & $7.324 \pm 0.140$ \\
\hline $\begin{array}{l}\text { Temperature } \\
\left({ }^{\circ} \mathrm{C}\right)\end{array}$ & $11.739 \pm 0.775$ & $11.552 \pm 1.342$ & $17.704 \pm 0.160$ & $19.475 \pm 0.952$ & $11.377 \pm 0.353$ & $10.521 \pm 0.077$ & $10.509 \pm 0.405$ & $9.283 \pm 0.304$ & $10.609 \pm 0.371$ & $9.283 \pm 0.304$ \\
\hline DTS (mg/L) & $3.096 \pm 0.069$ & $2.862 \pm 0.081$ & $9.200 \pm 1.397$ & $9.238 \pm 1.704$ & $2.577 \pm 0.066$ & $2.363 \pm 0.308$ & $2.625 \pm 0.0 .199$ & $2.513 \pm 0.160$ & $2.752 \pm 0.061$ & $2.354 \pm 0.219$ \\
\hline $\begin{array}{l}\text { Total } \\
\text { phosphorus } \\
\text { (mg/L) }\end{array}$ & $0.042 \pm 0.006$ & $0.041 \pm 0.007$ & $1.519 \pm 0.036$ & $1.498 \pm 0.012$ & $0.802 \pm 0.019$ & $0.792 \pm 0.001$ & $0.500 \pm 0.038$ & $0.503 \pm 0.046$ & $0.740 \pm 0.008$ & $0.760 \pm 0.003$ \\
\hline $\begin{array}{l}\text { Nitrates } \\
(\mathrm{mg} / \mathrm{L})\end{array}$ & $0.396 \pm 0.023$ & $0.409 \pm 0.039$ & $0.768 \pm 0.029$ & $0.762 \pm 0.034$ & $0.466 \pm 0.003$ & $0.466 \pm 0.003$ & $1.506 \pm 0.023$ & $1.314 \pm 0.510$ & $1.555 \pm 0.037$ & $1.480 \pm 0.011$ \\
\hline $\begin{array}{l}\text { Total iron } \\
\text { (mg/L) }\end{array}$ & $0.034 \pm 0.001$ & $0.034 \pm 0.001$ & $0.044 \pm 0.000$ & $0.054 \pm 0.000$ & $0.033 \pm 0.000$ & $0.033 \pm 0.000$ & $0.017 \pm 0.000$ & $0.017 \pm 0.000$ & $0.038 \pm 0.000$ & $0.038 \pm 0.000$ \\
\hline $\begin{array}{l}\text { Total copper } \\
(\mathrm{mg} / \mathrm{L})\end{array}$ & $0.002 \pm 0.000$ & $0.002 \pm 0.000$ & $0.005 \pm 0.001$ & $0.006 \pm 0.001$ & $0.002 \pm 0.000$ & $0.002 \pm 0.000$ & $0.002 \pm 0.000$ & $0.002 \pm 0.000$ & $0.002 \pm 0.001$ & $0.002 \pm 0.001$ \\
\hline $\begin{array}{l}\text { Total lead } \\
(\mathrm{mg} / \mathrm{L})\end{array}$ & $0.000 \pm 0.000$ & $0.001 \pm 0.000$ & $0.000 \pm 0.000$ & $0.000 \pm 0.000$ & $0.000 \pm 0.000$ & $0.000 \pm 0.000$ & $0.001 \pm 0.000$ & $0.000 \pm 0.000$ & $0.000 \pm 0.000$ & $0.000 \pm 0.000$ \\
\hline $\begin{array}{l}\text { Total zinc } \\
\text { (mg/L) }\end{array}$ & $0.000 \pm 0.000$ & $0.001 \pm 0.001$ & $0.000 \pm 0.000$ & $0.000 \pm 0.000$ & $0.000 \pm 0.000$ & $0.000 \pm 0.000$ & $0.000 \pm 0.000$ & $0.000 \pm 0.000$ & $0.000 \pm 0.000$ & $0.000 \pm 0.000$ \\
\hline
\end{tabular}

body of water [Rim et al. 2017] and to wastewater discharges [Christia et al. 2014]. However, these variations are within the natural ranges for aquatic life, according to the environmental quality standards for water in Peru [MINAM 2015], as well as within the ranges established by the WHO (2011) and the Canadian Council of Ministers of the Environment [CMME 2007]. Similar behavior was exhibited by the electrical conductivity, registering the highest values in the Tragadero lagoon in both sampling seasons, this result would be related to the pollutant load of organic matter contributed by the wastewater of the anthropogenic activities that develop in its surroundings [Alam et al. 2016].

The highest average values of the chemical oxygen demand - COD - were registered in the Tragadero lagoon, in both seasons, and were higher than the RCTs $(40 \mathrm{mg} / \mathrm{L})$. On the other hand, the $\mathrm{BOD}_{5}$ recorded in all the study gaps far exceeded the environmental quality standards for water $(10 \mathrm{mg} / \mathrm{L})$, revealing the deterioration of quality that these bodies of water are experiencing. Moreover, the average concentrations of dissolved oxygen-DO were lowest in the Tragadero lagoon, during the dry season, indicating the deterioration of the water quality in this lagoon and the effect on the chemical, photosynthetic and respiratory processes that occur in the water [Kuzmanovic et al. 2017]. The mean values of the highest temperature were recorded in the lagoon of Nahuinpuquio (19.475 \pm 0.952$)$ during the dry season. The mean values of total dissolved solids-TDS ranged from $2.363 \pm 0.308$ to
$9.238 \pm 1.704$ in the Cuncancocha and Tragadero lagoons, respectively.

The mean values of total phosphorus were higher than the environmental quality standards for water $(0.035 \mathrm{mg} / \mathrm{L})$, in all the lagoons evaluated, mainly in the Tragadero lagoon that presents values that triplicate to the phosphorus concentrations of the rest of the lagoons, confirming the problems of eutrophication that this body of water is experiencing [Copetti et al. 2015]. Additionally, the highest average values of nitrates were registered in this lagoon. The obtained results of these two nutrients reveal the pressure that these bodies of water are supporting, such as the discharge of domestic and industrial wastewater; as well as the drainage of the cultivated fields installed in its surroundings. Regarding the average concentration of $\mathrm{Cu}, \mathrm{Pb}$ and $\mathrm{Zn}$, the results found in the lagoons evaluated did not exceed the environmental quality standards of Peru, unlike the $\mathrm{Fe}$ that exceeded the values of the referred quality standards.

The PCA result of the physicochemical parameters and the sampling points in the five lagoons reveals the variability explained by each of the axes of variation (Figure 2). The first two axes explained $73 \%$ of the total variation and corresponded to the sampling points of the Tragadero lagoon. The first axis was closely related to high concentrations of iron and total dissolved solids. The second axis of variation was characterized by high concentrations of total phosphorus, COD and $\mathrm{BOD}_{5}$. The rest of the physicochemical indicators explain little of the total variability. 


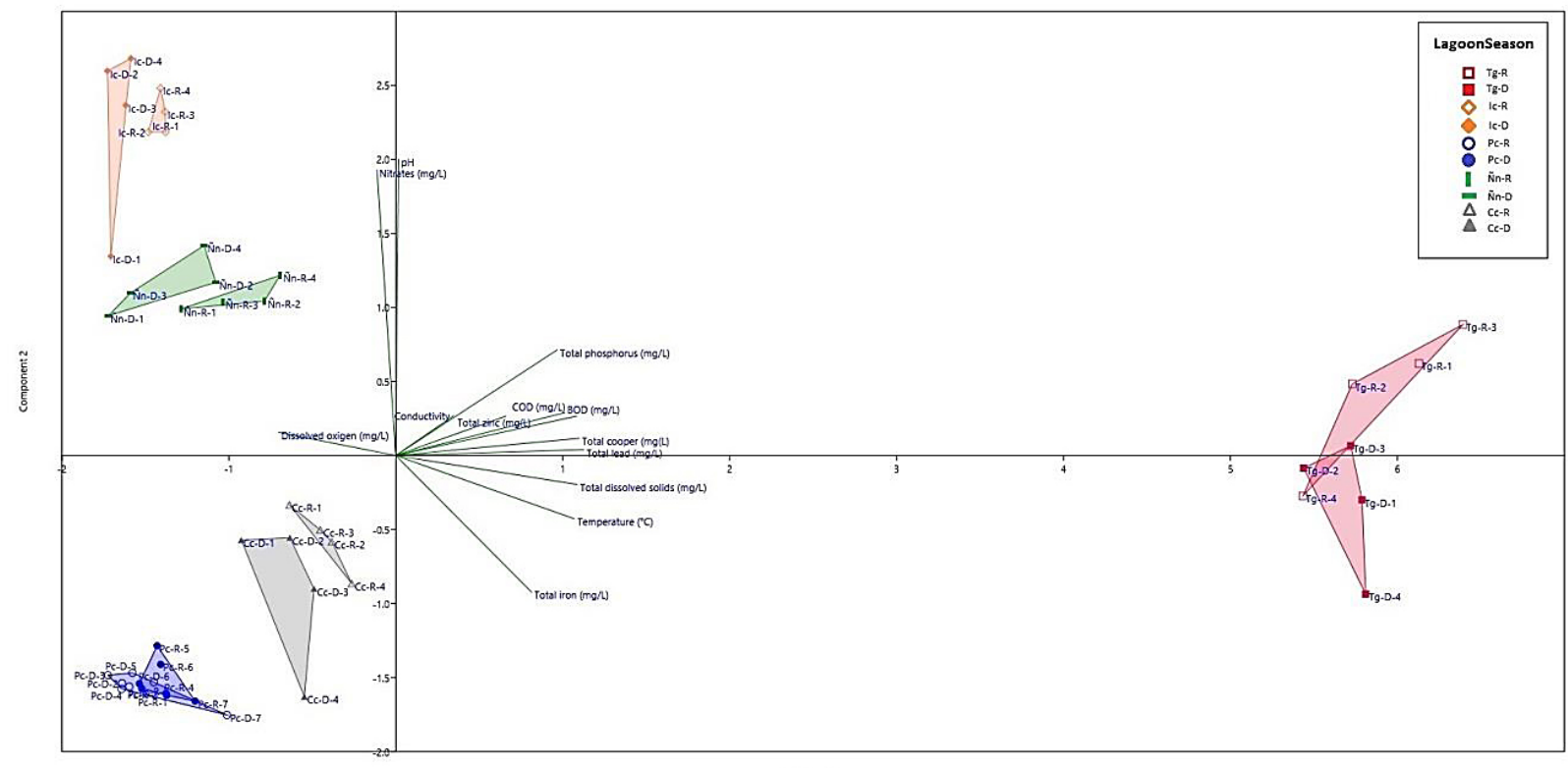

Figure 2. Analysis of the main components (PCA) of the physicochemical parameters of the water of high Andean lagoons, according to the time of sampling. Sampling included the lagoons: Incacocha in rainy season (Ic-R) and dry season (Ic-D); Nahuinpuquio (Ñn-R and Ñn-D), Cuncancocha (Cc-R and Cc-D), Pomacocha (Pc-R and Pc-D) and Tragadero (Tg-R and Tg-D).

The PERMANOVA analysis for the interaction of the lagoon factors by sampling period, at a level of significance of 0.01 , reveals that at least one of the observations resulting from this interaction, with respect to the physicochemical parameters of the water, is different from the others. In addition, the gradual analysis in pairs for the rainy season exhibits that the lagoons evaluated present significant differences, except the Pomacocha lagoon. The Tragadero and Incacocha lagoons show significant differences in relation due to the effect of the sampling period factor, that is, the values of the physicochemical parameters of the water are different both in the rainy season and in the dry season. On the other hand, for the Cuncancocha and Nahuinpuquio lagoons, the sampling period factor does not influence the physicochemical characteristics of the water and it is possible to affirm that they are statistically similar to a level of significance of 0.05 .

\section{Analysis of benthic macroinvertebrate communities}

A total of 4905 individuals of benthic macroinvertebrates were captured during the sampling periods in five high-Andean lagoons of the Junín region, which corresponded to nine orders and 14 families. The largest number of individuals of benthic macroinvertebrates was presented by the order Diptera with 3992 individuals, followed by the order Ephemeroptera with 429 individuals. The highest density of benthic macroinvertebrates was recorded in the Tragadero lagoon in both sampling seasons, corresponding to the order Diptera. However, the composition of the taxa by taxonomic orders showed slight variations during the sampling periods, Diptera, Ephemeroptera, Coleoptera and Trichoptera were the orders with the highest taxa richness.

The SIMPER analysis carried out to analyze the composition of the benthic macroinvertebrate communities of the five high Andean lagoons determined an average of four families per lagoon that showed more than $70 \%$ contribution in the analysis. The families that contributed the most in the differentiation of these communities were: Chironomidae $(41.30 \%)$, Ceratopogonidae (11.97\%), Psychodidae (11.14\%) and Hidrophilidae $(9.11 \%)$. The contribution of the Chironomidae family in the composition of the macroinvertebrate communities varied according to time. The largest contributions of the Chironomidae family were made in the Tragadero lagoons, with $69.90 \%$ and Incacocha with $53.80 \%$, during the dry season and rain, respectively. These results coincide with those recorded in other studies in the aquatic environments with low oxygen levels, dominance of the Chironomidae and decrease in the density of other macroinvertebrates [Graeber 
Table 2. Average abundance and percentage of contribution (in parentheses) of families of benthic macroinvertebrates according to the lagoon factor in the SIMPER analysis

\begin{tabular}{|c|c|c|c|c|c|c|c|c|c|c|c|c|c|c|c|c|c|c|c|c|c|}
\hline \multirow{3}{*}{ Taxa } & \multirow{3}{*}{\begin{tabular}{|c|}
$\begin{array}{c}\text { Pool } \\
\text { all } \\
\text { groups }\end{array}$ \\
$\begin{array}{c}\text { Contr. } \\
\%\end{array}$ \\
\end{tabular}} & \multicolumn{10}{|c|}{ Rainy season } & \multicolumn{10}{|c|}{ Dry season } \\
\hline & & \multicolumn{2}{|c|}{$\mathrm{Pc}$} & \multicolumn{2}{|c|}{$\mathrm{Tg}$} & \multicolumn{2}{|c|}{ Cc } & \multicolumn{2}{|r|}{ Ic } & \multicolumn{2}{|c|}{$\tilde{N} n$} & \multicolumn{2}{|c|}{$\mathrm{Pc}$} & \multicolumn{2}{|c|}{$\mathrm{Tg}$} & \multicolumn{2}{|c|}{ Cc } & \multicolumn{2}{|c|}{ Ic } & \multicolumn{2}{|c|}{$\tilde{N} \mathrm{n}$} \\
\hline & & $\bar{x}$ & \begin{tabular}{|c|}
$\begin{array}{c}\text { Contr. } \\
\%\end{array}$ \\
\end{tabular} & $\bar{x}$ & $\begin{array}{c}\text { Contr. } \\
\%\end{array}$ & $\bar{x}$ & $\begin{array}{c}\text { Contr. } \\
\%\end{array}$ & $\bar{x}$ & $\begin{array}{c}\text { Contr. } \\
\%\end{array}$ & $\bar{x}$ & $\begin{array}{c}\text { Contr. } \\
\%\end{array}$ & $\bar{x}$ & $\begin{array}{c}\text { Contr. } \\
\%\end{array}$ & $\bar{x}$ & $\begin{array}{c}\text { Contr. } \\
\%\end{array}$ & $\bar{x}$ & $\begin{array}{c}\text { Contr. } \\
\%\end{array}$ & $\bar{x}$ & $\begin{array}{c}\text { Contr. } \\
\%\end{array}$ & $\bar{x}$ & $\begin{array}{c}\text { Contr. } \\
\%\end{array}$ \\
\hline Chironomidae & 41.3 & 19.3 & 37.7 & 78.5 & 67.1 & 15.3 & 49.3 & 21.0 & 53.8 & 20.8 & 41.4 & 64.3 & 55.4 & 84.0 & 69.9 & 20.8 & 34.9 & 23.3 & 44.1 & 23.8 & 49.3 \\
\hline Ceratopogonidae & 12.0 & 9.3 & 18.2 & 9.3 & 7.9 & 8.5 & 27.4 & 10.5 & 26.9 & 9.5 & 18.9 & 7.9 & 6.8 & 4.5 & 3.7 & 11.8 & 19.8 & 11.8 & 22.3 & 6.8 & 14.0 \\
\hline Psychodidae & 11.1 & 1.6 & 3.1 & 15.5 & 13.2 & 2.5 & 8.1 & 1.0 & 2.6 & 9.3 & 18.6 & 7.9 & 6.8 & 19.0 & 15.8 & 7.5 & 12.6 & 3.8 & 7.1 & 9.0 & 18.6 \\
\hline Hydrophilidae & 9.1 & 5.6 & 10.9 & 0.0 & 0.0 & 1.3 & 4.0 & 2.3 & 5.8 & 7.5 & 14.7 & 7.1 & 6.2 & 1.5 & 1.2 & 7.3 & 12.2 & 5.3 & 9.9 & 5.5 & 11.4 \\
\hline Baetidade & 8.5 & 6.4 & 12.6 & 2.8 & 2.4 & 1.3 & 4.0 & 1.5 & 3.8 & 2.8 & 5.5 & 10.3 & 8.9 & 2.0 & 1.7 & 5.5 & 9.2 & 5.3 & 9.9 & 0.0 & 0.0 \\
\hline Leptophlebiidae & 4.9 & 4.6 & 8.9 & 0.0 & 0.0 & 0.0 & 0.0 & 0.0 & 0.0 & 0.0 & 0.0 & 8.4 & 7.3 & 1.0 & 0.8 & 0.0 & 0.0 & 0.0 & 0.0 & 0.0 & 0.0 \\
\hline Tubificidae & 3.2 & 0.9 & 1.7 & 4.3 & 3.6 & 0.8 & 2.4 & 1.5 & 3.8 & 0.5 & 1.0 & 1.3 & 1.1 & 2.3 & 1.9 & 1.5 & 2.5 & 1.0 & 1.9 & 1.3 & 2.6 \\
\hline Limnephilidae & 3.1 & 1.9 & 3.6 & 0.0 & 0.0 & 1.5 & 4.8 & 1.3 & 3.2 & 0.0 & 0.0 & 2.4 & 2.1 & 0.0 & 0.0 & 1.8 & 2.9 & 2.0 & 3.8 & 1.3 & 2.6 \\
\hline Lymnaeidae & 2.6 & 0.0 & 0.0 & 5.8 & 4.9 & 0.0 & 0.0 & 0.0 & 0.0 & 0.0 & 0.0 & 1.0 & 0.9 & 3.5 & 2.9 & 1.0 & 1.7 & 0.0 & 0.0 & 0.8 & 1.6 \\
\hline Psychomyiidae & 1.6 & 1.0 & 2.0 & 0.0 & 0.0 & 0.0 & 0.0 & 0.0 & 0.0 & 0.0 & 0.0 & 3.3 & 2.8 & 0.0 & 0.0 & 0.0 & 0.0 & 0.0 & 0.0 & 0.0 & 0.0 \\
\hline Planariidae & 1.2 & 0.4 & 0.8 & 1.0 & 0.9 & 0.0 & 0.0 & 0.0 & 0.0 & 0.0 & 0.0 & 1.1 & 1.0 & 0.0 & 0.0 & 1.3 & 2.1 & 0.5 & 0.9 & 0.0 & 0.0 \\
\hline Glossiphoniidae & 0.8 & 0.0 & 0.0 & 0.0 & 0.0 & 0.0 & 0.0 & 0.0 & 0.0 & 0.0 & 0.0 & 0.3 & 0.2 & 2.5 & 2.1 & 0.5 & 0.8 & 0.0 & 0.0 & 0.0 & 0.0 \\
\hline Hyalellidae & 0.6 & 0.3 & 0.6 & 0.0 & 0.0 & 0.0 & 0.0 & 0.0 & 0.0 & 0.0 & 0.0 & 0.7 & 0.6 & 0.0 & 0.0 & 0.8 & 1.3 & 0.0 & 0.0 & 0.0 & 0.0 \\
\hline
\end{tabular}

et al. 2017]. The Pomacocha and Cuncancocha lagoons presented the lowest contributions of the Chironomidae family (Table 2).

The analysis of the differences in the relative abundances of the benthic macroinvertebrates in the five lagoons evaluated through the ANOSIM shows that the Tragadero lagoon differs significantly with respect to the others, except for the Pomacocha lagoon during the dry season. In addition, it is observed that the Cuncancocha, Incacocha and Nahuinpuquio lagoons have significant similarities (Table 3). These results reveal that the great majority of benthic macroinvertebrate species have low tolerance to contamination [Johnson and Ringler 2014].

The non-metric multidimensional scaling analysis shows an average value of stress level of 0.14 , which according to the range given by Kruskal indicates a regular interpretation in the perceptual map. Most of the sampling points of the lagoons evaluated are grouped, regardless of the sampling period. It is observed that the sampling points in the Tragadero lagoon tend to be clearly separated from the rest of the sampling points of the other lagoons. A similar behavior is shown by one of the sampling points in the Pomacocha lagoon. This is explained by the marked differences in the abundances of Chironomidae species that these lagoons have. The abundance of these species in the rest of the lagoons is low.

The PERMANOVA analysis for the interaction of the lagoon factors by sampling period, at a level of significance of 0.05 , reveals that at least one of the observations resulting from this interaction influences the biological values, that is, at least one of the observations in a certain lagoon and sampling period is different from the others in relation to the number of species and abundances. Moreover, when performing the test as a pair (Pair-Wise) it was found that for the rainy

Table 3. ANOSIM pair-wise test results for the multivariate diversity test

\begin{tabular}{|c|c|c|c|c|c|c|c|c|c|c|}
\hline & PcR & TgR & CcR & IcR & NnR & PcD & TgD & CcD & IcD & NnD \\
\hline PcR & & & & & & & & & & \\
\hline TgR & 0.0025 & & & & & & & & & \\
\hline CcR & $\mathbf{0 . 1 7 5}$ & 0.0292 & & & & & & & & \\
\hline IcR & $\mathbf{0 . 5 2 2 6}$ & 0.0307 & $\mathbf{0 . 7 1 7 3}$ & & & & & & & \\
\hline ÑnR & $\mathbf{0 . 0 5 3 6}$ & 0.0259 & $\mathbf{0 . 0 8 4}$ & $\mathbf{0 . 1 1 0 9}$ & & & & & & \\
\hline PcD & 0.0005 & $\mathbf{0 . 1 5 0 2}$ & 0.0022 & 0.0055 & 0.0057 & & & & & \\
\hline TgD & 0.0033 & $\mathbf{0 . 8 0 4 6}$ & 0.027 & 0.0275 & 0.0287 & $\mathbf{0 . 0 6 1 5}$ & & & & \\
\hline CcD & 0.0462 & 0.0298 & $\mathbf{0 . 1 3 9 5}$ & $\mathbf{0 . 1 9 3 3}$ & $\mathbf{0 . 9 1 4 1}$ & 0.0054 & 0.029 & & & \\
\hline IcD & $\mathbf{0 . 1 8 9 3}$ & 0.0309 & $\mathbf{0 . 1 1 1 3}$ & $\mathbf{0 . 6 2 7 9}$ & $\mathbf{0 . 8 0 3 9}$ & 0.0063 & 0.0286 & $\mathbf{0 . 9 7 2 7}$ & & \\
\hline$\tilde{N} n D$ & 0.018 & 0.0287 & $\mathbf{0 . 0 8 9 8}$ & $\mathbf{0 . 0 5 7}$ & $\mathbf{0 . 7 7 0 6}$ & 0.009 & 0.0296 & $\mathbf{0 . 4 3 1 5}$ & $\mathbf{0 . 2 2 8 1}$ & \\
\hline
\end{tabular}


season the Incacocha and Cuncancocha lagoons are highly similar for the biological indexes. For the Pomacocha and Incacocha lagoons, the distribution of observations is greatly dispersed. In contrast, the Laguna Tragadero maintains a significant difference between all the lagoons. The Cuncancocha, Nahuinpuquio and Incacocha lagoons are statistically similar, making these lagoons grouped in relation to their biological indices, forming three similarity groups, the Pomacocha lagoon that differs from Tragadero, and this differs from the Cuncancocha, Nahuinpuquio and Incacocha lagoons (Figure 3).

The stepped analysis shows that in the Pomacocha lagoon, the effect of the sampling period factor influences the biological indexes, showing that they differ and change in number of species and abundances due to the effect of the sampling period. In the case of the Tragadero, Cuncancocha, Incacocha and Ñahuinpuquio lagoons, the sampling period factor does not influence diversity indices.

\section{Correlation of biological and environmental variables}

The correlation of the biological variables (abundance of benthic macroinvertebrates) and environmental variables (physicochemical parameters of the water), for the rainy season, through the Spearman correlation coefficient showed a Rho value of 0.60 . This result reveals that the distribution of the dissimilarities of the environmental variables is similar to the biological variables (Figure 4). While performing matrix resemblance pairing analysis, it was found that the Rho is 0.32 (Spearman rank), using the two factors (lagoon and sampling time). This result indicates that the biological variables show the same dispersion pattern as the environmental variables at $32 \%$ similarity. Although this value is very low, it is possible that the dispersion of the biological data is influencing the decrease of this value, especially in the dry season, where the

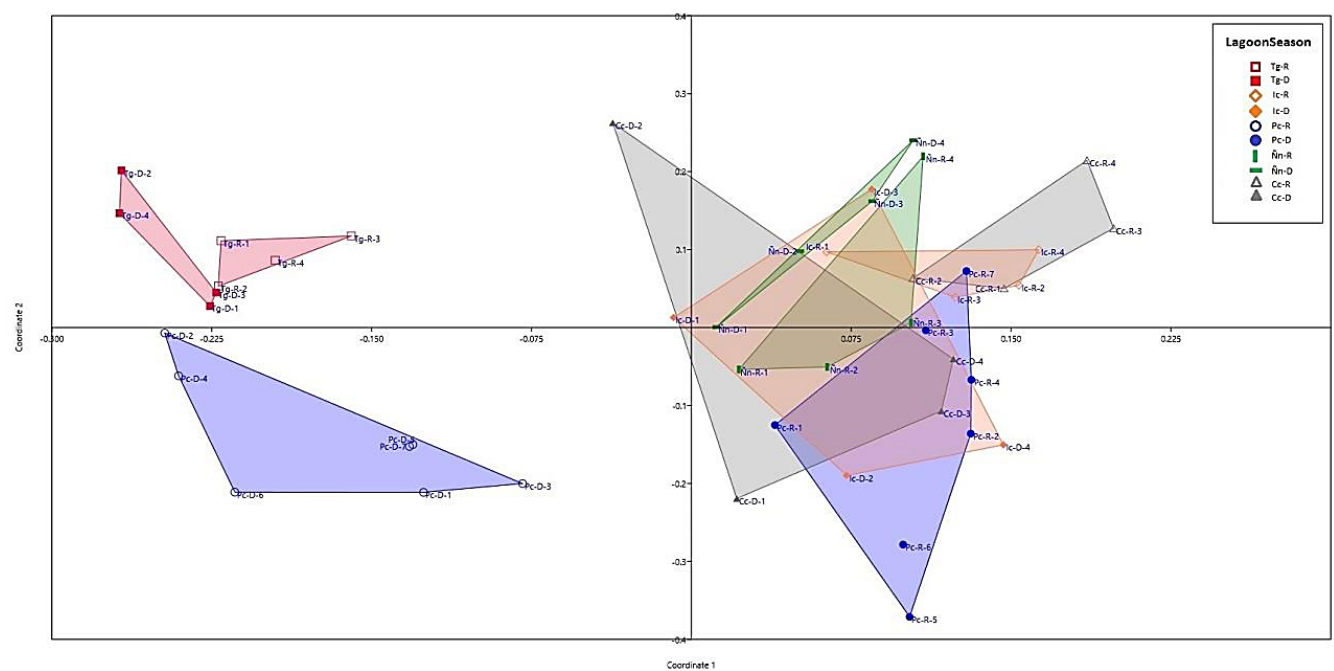

Figure 3. Analysis of principal coordinates (PCO) of the composition of the communities of benthic macro invertebrates, using similarity of Bray - Curtis for each high Andean lagoon, during the rainy and dry periods.

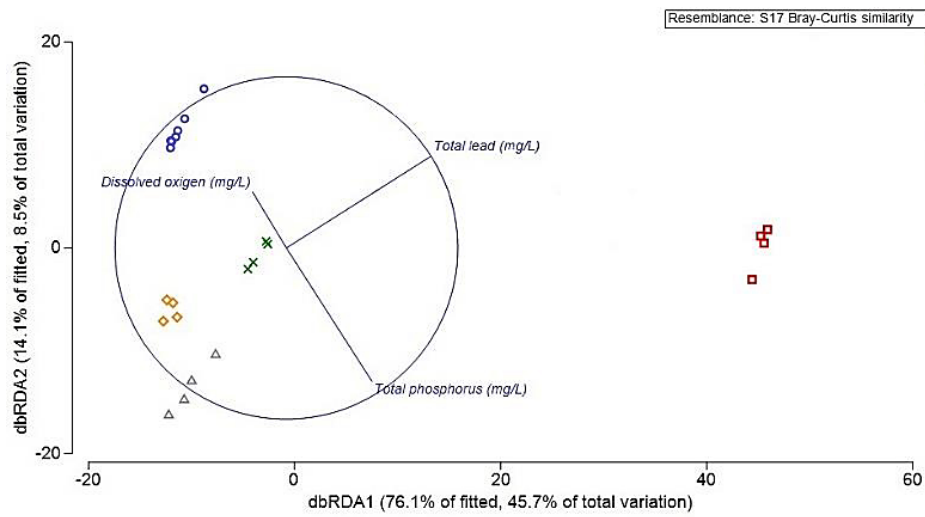

Figure 4. Analysis of linear models based on the comparison distance according to the lagoon factor evaluated for the rainy period. 
biological indices are very different. However, the distribution given by the main environmental vectors would be revealing that the abundance of the species of the families Leptophlebiidae and Psychodidae in the Pomacocha lagoon would be determined by the low values of the environmental variables in general. The species of the Lymnaeidae and Glossiphoniidae families are species that are present in areas with high values of total phosphorus, $\mathrm{COD}, \mathrm{BOD}_{5}$, zinc, copper, lead, total dissolved solids, temperature and iron; as in the Tragadero lagoon.

It is normal that as the number of variables increases, the value of the relationship decreases; but this large decrease indicates that in the dry season there are phenomena that condition the increase in the number of species and abundance in the Pomacocha lagoon especially, causing the biological matrix to have a poor relationship with the distribution of the environmental variables. According to the individual analysis using the lagoon factor for the dry season, the correlation value is 0.30 , showing the Pomacocha lagoon ex- periences a great increase in its biological values, simultaneously increasing the presence of species that are similar to the characteristics of the Tragadero lagoon, the most contaminated, with similarities in the number of species and $60 \%$ abundance. According to the analysis of linear models based on distance, this behavior in the Tragadero and Pomacocha lagoons is explained by the increase in temperature in the water and the high levels of lead, especially in the Tragadero lagoon (Figure 5).

The sequential analysis of linear models based on distance (DistLM) using the two factors (lagoon and period) shows that the predominant predictors presented a value of 0.46 of coefficient of determination out of a total of 0.58 , where all the physicochemical variables participated, being observed that the values of total lead, phosphorus and conductivity are the most important in relation to the distribution of biological data. However, the highest total lead values are presented by the Tragadero lagoon and phosphorus lagoons, the second important variable, the Tra-

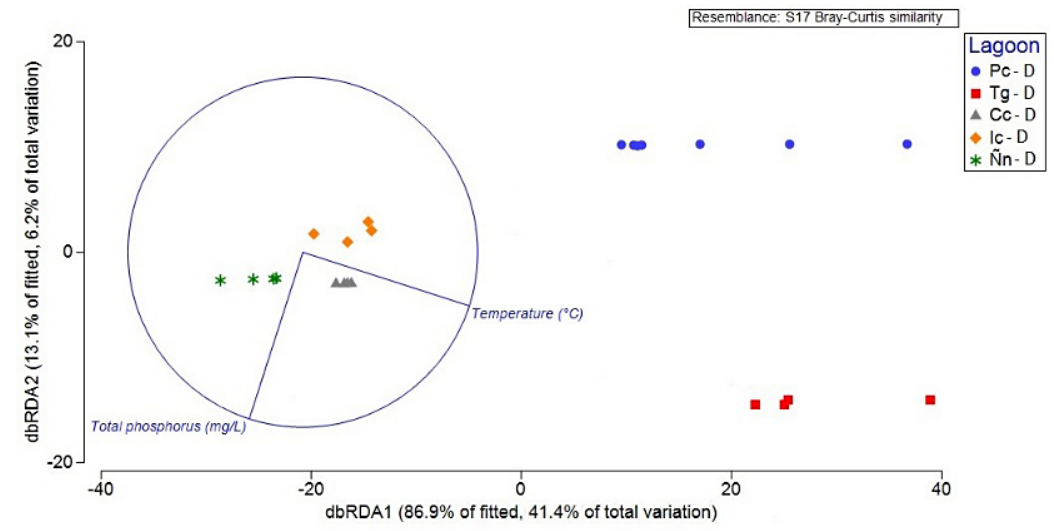

Figure 5. Analysis of linear models based on the comparison distance according to the lagoon factor evaluated for the dry period.

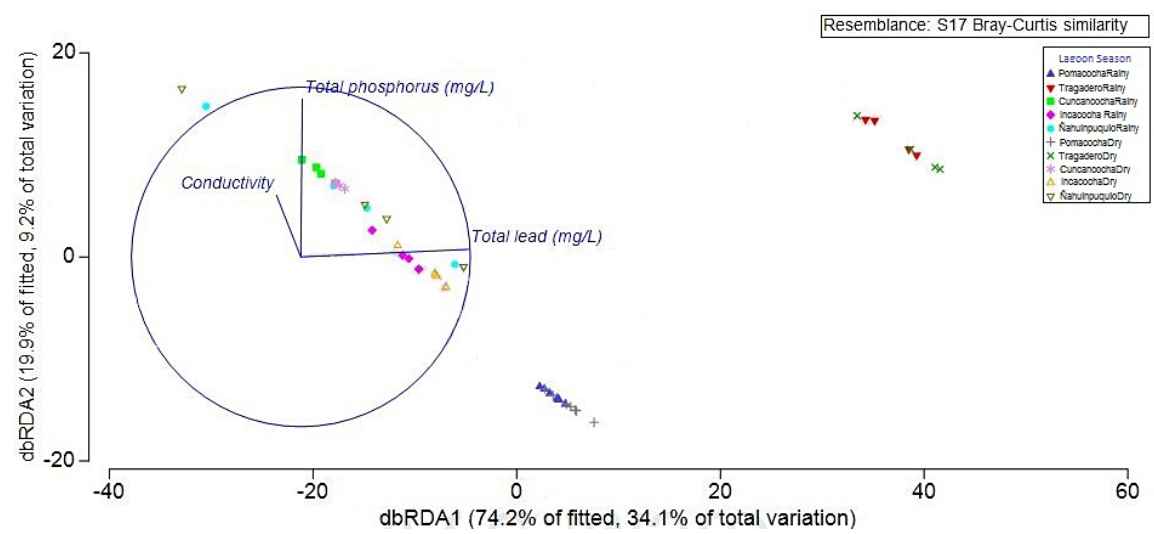

Figure 6. Analysis of linear models based on comparison distance between the interaction of sampling time and lagoon. 
gadero and Pomacocha lagoons; which explains the greater abundance of benthic macroinvertebrates in these bodies of water, mainly of the Chironomidae family (Figure 6), considered as the resistant and resilient taxon against anthropogenic pressures [Ruaro 2014].

The BEST (Biota and enviromental matching) analysis reveals that using all the observations divided by the two evaluation factors (lagoon and period), the biological matrices (with a Rho $=0.462$ ) are explained by the environmental variables of temperature, phosphorus and lead total.

\section{CONCLUSIONS}

The quality of the aquatic environment of high Andean lagoons evaluated by multivariate statistical methods presents important differences not only in the physicochemical characteristics of the water, but also in the composition of the benthic macroinvertebrate communities. The anthropogenic activities developed in and around the lagoons are affecting the quality of the water and as a consequence to the biological communities, altering their composition; such as it is observed in the Tragadero lagoon. In addition, the sampling period factor influences the number and abundance of benthic macroinvertebrate species. In the rainy season, the correlation of the physicochemical variables has a good degree of adjustment (around 60\%), indicating that there is a good correspondence and explanation of the behavior exhibited by the biological communities. Thus, the Tragadero lagoon has higher indices of abundance and dominance of the Chironomidae family, in response to the strong pressures exerted by anthropogenic activities. Therefore, the most important predictors of the environmental quality of these bodies of water are total lead, phosphorus and conductivity.

\section{Acknowledgements}

The authors express their gratitude to the General Research Institute of the National University of Central Peru for the financing of the study, to the Water Research Laboratory for allowing us to make use of the equipment and materials for this study, to M. Sc. Samuel Pizarro for his assistance in field sampling and to Eng. Cirilo Sedano Fuentes for his valuable collaboration in the translation of the manuscript.

\section{REFERENCES}

1. Alam, M.Z., Carpenter-Boggs, L., Rahman, A., Haque, M.M., Miah, M.R.U., Moniruzzaman, M., Qayum, M.A., Abdullah, H.M., 2016. Water quality and resident perceptions of declining ecosystem services at Shitalakka wetland in Narayanganj city. Sustainability of Water Quality and Ecology. doi: 10.1016/j.swaqe.2017.03.002

2. Article, O., 2015. Development and evaluation of the Lake Multi-biotic Integrity Index for Dongting Lake, China. J. Limnol 74, 594-605. doi: 10.4081/ jlimnol.2015.1186

3. Bharti, N., 2011. Water quality indices used for surface water vulnerability assessment. International Journal of Environmental Sciences 2, 154-173.

4. Canadian Council of Ministers of the Environment (CMME), 2007. Canadian water quality guidelines for the protection of aquatic life, Canadian water quality guidelines.

5. Ceschia, C., Falace, A., Warwick, R., 2007. Biodiversity evaluation of the macroalgal flora of the Gulf of Trieste (Northern Adriatic Sea) using taxonomic distinctness indices. Hydrobiologia 580, 43-56. doi: 10.1007/s10750-006-0466-8

6. Christia, C., Giordani, G., Papastergiadou, E., 2014. Assessment of ecological quality of coastal lagoons with a combination of phytobenthic and water quality indices. Marine Pollution Bulletin 86, 411-423. doi:10.1016/j.marpolbul.2014.06.038

7. Clarke, K., Gorley, R., 2015. Primer v7: User Manual/Tutorial, in: Plymouth, Uk. pp. 1-296. doi: 10.1111/j.1442-9993.1993.tb00438.x

8. Clarke, K.R., Gorley, R.N., 2006. PRIMER v6: User Manual/Tutorial. PRIMER-E, Plymouth UK 192 p. doi: 10.1111/j.1442-9993.1993.tb00438.x

9. Clesceri, L.S., Greenberg, A.E., Eaton, A.D., 2012. Standard Methods for the Examination of Water and Wastewater, in: Standard Methods for the Examination of Water and Wastewater. p. 733.

10. Copetti, D., Finsterle, K., Marziali, L., Stefani, F., Tartari, G., Douglas, G., Reitzel, K., Spears, B.M., Winfield, I.J., Crosa, G., D'Haese, P., Yasseri, S., Lürling, M., 2015. Eutrophication management in surface waters using lanthanum modified bentonite: A review. Water Research 97, 162-174. doi: 10.1016/j.watres.2015.11.056

11. Graeber, D., Jensen, T.M., Rasmussen, J.J., Riis, T., Wiberg-Larsen, P., Baattrup-Pedersen, A., 2017. Multiple stress response of lowland stream benthic macroinvertebrates depends on habitat type. Science of the Total Environment 599-600, 1517-1523. doi: 10.1016/j.scitotenv.2017.05.102

12. Ignatiades, L., Gotsis-Skretas, O., Pagou, K., Krasakopoulou, E., 2009. Diversification of phytoplankton community structure and related pa- 
rameters along a large-scale longitudinal eastwest transect of the Mediterranean Sea. Journal of Plankton Research 31, 411-428. doi: 10.1093/ plankt/fbn124

13. Johnson, S.L., Ringler, N.H., 2014. The response of fish and macroinvertebrate assemblages to multiple stressors: A comparative analysis of aquatic communities in a perturbed watershed (Onondaga Lake, NY). Ecological Indicators 41, 198-208. doi: 10.1016/j.ecolind.2014.02.006

14. Kuzmanovic, M., Dolédec, S., de Castro-Catala, N., Ginebreda, A., Sabater, S., Muñoz, I., Barceló, D., 2017. Environmental stressors as a driver of the trait composition of benthic macroinvertebrate assemblages in polluted Iberian rivers. Environmental Research 156, 485-493. doi: 10.1016/j.envres.2017.03.054

15. NME, 2015. Supreme Decree N $N^{\circ}$ 015-2015NME - National Environmental Quality Standards for Water. Official Newspaper El Peruano 3.

16. NME, 2011. National Environmental Action Plan 2011-2021. NME 2021.

17. Muangthong, S., Shrestha, S., 2015. Assessment of surface water quality using multivariate statistical techniques: case study of the Nampong River and Songkhram River, Thailand. Environmental Monitoring and Assessment 187. doi: 10.1007/ s10661-015-4774-1

18. Petus, C., Marieu, V., Novoa, S., Chust, G., Bruneau, N., Froidefond, J.M., 2014. Monitoring spatio-temporal variability of the Adour River turbid plume (Bay of Biscay, France) with MODIS 250$\mathrm{m}$ imagery. Continental Shelf Research 74, 35-49. doi: 10.1016/j.csr.2013.11.011

19. Primo, A.L., Marques, S.C., Falcão, J., Crespo, D., Pardal, M.A., Azeiteiro, U.M., 2012. Environmental forcing on jellyfish communities in a small temperate estuary. Marine Environmental Research 79, 152-159. doi: 10.1016/j.marenvres.2012.06.009

20. Rim, A., Charff, A., Ayed, L., Khadhar, S., 2017. Effect of Water Quality on Heavy Metal Redistribution-Mobility in Agricultural Polluted Soils in Semi-Arid Region. Pedosphere 160. doi: 10.1016/ S1002-0160(17)60367-9

21. Ruaro, R., 2014. A scientometric assessment of 30 years of the Index of Biotic Integrity in aquatic ecosystems : Applications and main flaws. Ecological Indicators 29, 105-110. doi: 10.1016/j. ecolind.2012.12.016

22. Seiler, L.M.N., Helena, E., Fernandes, L., Martins, F., Cesar, P., 2015. Evaluation of hydrologic influence on water quality variation in a coastal lagoon through numerical modeling. Ecological Modelling 314, 44-61. doi: 10.1016/j.ecolmodel.2015.07.021

23. Swiech, T., Ertsen, M.W., Pererya, C.M., 2012. Estimating the impacts of a reservoir for improved water use in irrigation in the Yarabamba region, Peru. Physics and Chemistry of the Earth 47-48, 64-75. doi: 10.1016/j.pce.2011.06.008

24. Wen, S., Shan, B., Zhang, H., 2012. Metals in sediment/pore water in Chaohu Lake: Distribution, trends and flux. Journal of Environmental Sciences (China) 24, 2041-2050. doi: 10.1016/ S1001-0742(11)61065-6

25. WHO, 2011. WHO | Guidelines for drinking-water quality, fourth edition [WWW Document]. WHO. 